\title{
PENGARUH PEMBELAJARAN BERBASIS MASALAH DENGAN PENGUATAN KETERAMPILAN FLEKSIBILITAS TERHADAP HASIL BELAJAR KOGNITIF
}

\author{
Agung Aprianto*, Henry Praherdhiono, Agus Wedi
}

Teknologi Pendidikan, Fakultas Ilmu Pendidikan, Universitas Negeri Malang

\section{Edcomtech}

\section{Jurnal Kajian Teknologi Pendidikan}

Volume 6, No 2, Oktober 2021

264-274

DOI: $10.17977 /$ um039v6i12021p264

Submitted $17-10-2020$

Accepted 02-12-2020

\section{Corresponding Author*}

Agung Aprianto

Universitas Negeri Malang

Jl. Semarang No.5, Sumbersari, Kec. Lowokwaru, Kota Malang, Jawa Timur 65145, Indonesia Email:

apriantoagung639@gmail.com

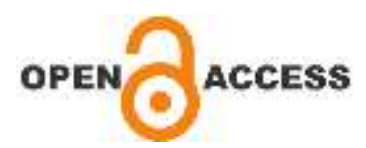

\begin{abstract}
Abstrak
Riset ini bertujuan membuktikan pengaruh pembelajaran Problem Based Learning dengan penguatan keterampilan fleksibilitas terhadap hasil belajar kognitif pada peserta didik kelas VII. Dalam pembelajaran ini peserta didik diajarkan untuk berpikir fleksibel dalam memecahkan masalah terkait materi energi dalam kehidupan. Dalam riset ini mengaplikasikan desain quasi eksperimen. Subjek dalam riset ini merupakan semua peserta didik kelas VII A dan VII B berjumlah 50 peserta didik. Teknik pengumpulan data yang digunakan adalah teknik tes. Pretest dilakukan untuk mengambil data kemampuan awal peserta didik, sedangkan posttest dilakukan untuk menguji pengaruh perlakuan. Dalam riset ini dilakukan 3 uji statistic yaitu, (1) uji normalitas, (2) uji homogenitas, (3) uji hipotesis. Hasil analisis hipotesis diperoleh $\mathrm{H1}$ diterima karena nilai signifikansinya 0,001 < 0,05 sehingga dapat disimpulkan bahwa terdapat pengaruh Problem Based Learning (PBL) dengan penguatan keterampilan fleksibilitas pada mata pelajaran IPA terhadap hasil belajar kognitif.
\end{abstract}

Kata Kunci: Problem Based Learning (PBL); Fleksibilitas Kognitif; Hasil Belajar

\begin{abstract}
This research proves the influence of Problem Based Learning by strengthening flexibility skills on cognitive learning outcomes in grade VII students. In study the students are taught to think flexibly in order to resolve the problem that is related to the energy life. The type of Research used is quasi-experimental. The data collection technique used is the test technique. The pretest is done to retrieve a students' initial ability data, while the posttest is conducted to test the effect of treatment. In This research, three statistical tests will be carried out namely, (1) normality test, (2) homogeneity test, (3) hypothesis test. The results of the hypothesis analysis obtained $\mathrm{H} 1$ were received because the significance value was $0.001<0.05$, so it can be concluded that there is influence of Problem Based Learning (PBL) by strengthening flexibility skills in science subjects on the learning outcomes of cognitive learning.

Keywords: Problem Based Learning (PBL); Cognitive Flexibility; Learning outcomes
\end{abstract}

\section{LATAR BELAKANG}

Pembelajaran Berbasis Masalah merupakan model yang memiliki relevansi terhadap kebutuhan kehidupan. Kondisi era abad 21 memiliki konten permasalahan positif dan konten permasalahan negatif. Konten perma-salahan negatif yang dirasakan era abad 21, merupakan konten permasalahan efek rumah kaca (Chen et al., 
2020). Permasalahan tersebut berkaitan dengan meningkatnya banyaknya pemakaian gas-gas yang ada dalam rumah kaca akan menjadi sumber memicu terjadinya perubahan iklim secara luas (Kusumo, 2020). Permasalahan era abad 21 seperti efek rumah kaca sangat relevan untuk diselesaikan melalui model Problem Based Learning (PBL). Problem Based Learning ( $P B L$ ) memiliki basis pemecahan terhadap masalah (Asdiansyah et al., 2020).

Permasalahan yang sering diangkat dalam pembelajaran memerlukan keterampilan fleksibilitas. Fleksibilitas tersebut merupakan keterampilan untuk memperoleh infor-masi hingga pebelajar mampu memecahkan permasalahan (Toraman et al., 2020). Salah satu wujud permasalahan kekinian saat adalah bagaimana mengurangi pemanasan global secara melalui upaya ilmiah. Keterampilan fleksibilitas memiliki peran untuk menjadikan seseorang yang berkualitas, dengan cara orang tersebut bisa mengetahui dan mampu menerapkan pengetahuannya untuk memecahkan masalah.

Keterampilan fleksibilitas sangat penting sebagai penguatan pada PBL. Secara umum, pendidikan memiliki tujuan penting untuk menumbuhkan suatu kebiasan berpikir untuk peserta didik mampu menyelesaikan suatu masalah yang dihadapinya, dengan adanya peserta didik memiliki kemampuan berpikir cerdas dalam wujud keterampilan fleksibilitas untuk mengatasinya, dimana individu bukan hanya dengan memiliki informasi namun harus memiliki suatu cara dalam menyelesaikan masalah tersebut. Kebiasaan berpikir sering dinyatakan sebagai kemahiran berpikir (habits of mind) (Butler, 2020).

Habits of Mind memiliki keterkaitan dengan aspek kognitif setelah lulus dari sebuah pendidikan yang baik, akan sangat memerlukan proses belajar sehingga hasil belajar dengan cara yang berkualitas. Kualitas pembelajaran diwujudkan dengan penilaian cara untuk mengetahui proses dan hasil belajar dalam habit of mind (Gloria et al., 2020). Hasil tersebut dapat diukur dengan adanya perubahan kognitif, afektif maupun psikomotorik

Pendekatan terhadap model pembelajaran merupakan cara untuk mengintervensi peningkatan hasil belajar. Metode belajar yang relevan dengan karakter peserta didik dengan karakteristik konten akan memberikan kenyamanan secara psikis (Darmawan et al., 2020; Praherdhiono et al., 2018). Habits of mind merupakan kondisi baru yang dibangun oleh peserta didik sendiri sebagai upaya dalam memecahkan permasalahan. Langkahlangkah dalam menyelesaikan masalah berpikir secara cerdas merupakan usaha nyata berpikir kritis dengan penguatan keterampilan fleksibilitas. Hasil belajar lebih bermakna bagi peserta didik apabila secara mandiri mampu menyelesaikan masalah, berpikir kritis dengan cara menerapkan keterampilan fleksibilitas, sehingga mampu untuk membuat keputusan yang tepat dalam menyelesaikan masalah.

Habits of mind dalam wujud keterampilan fleksibilitas dikaitkan dengan kecerdasan seseorang dalam bertindak. Menurut pendapat dari pakar keilmuan mencoba untuk mengem-bangkan habits of mind (keterampilan berpikir) melalui berbagai riset. habits of mind merupakan karakteristik peserta didik dalam tingkat untuk berpikir cerdas pada kategori tertinggi dalam berpikir sehingga peserta didik mampu menyelesaikan masalah yang dihadapi dengan berlandaskan karakteristik keberhasilan dalam pendidikan (Costa \& Kallick, 2008). Peserta didik yang memiliki kebiasaan berpikir dengan keterampilan fleksibilitas bisa memiliki suatu pemikiran yang berbeda,dan memiliki kemampuan dalam berpikir yang berupa memberikan suatu ide atau saran yang berbeda dan mengerjakan dengan cara yang efektif. Dengan uraian yang dijelaskan maka sangat dibutuhkan suatu metode pembelajaran yang sesuai untuk meningkatkan cara 
berpikir dengan keterampilan fleksibilitas yaitu model Problem Based Learning (PBL). Arends (2008) menjelaskan bahwasanya Problem Based Learning (PBL) merupakan suatu metode pembelajaran yang memiliki karakteristik yaitu memberikan suatu masalah yang bermakna untuk peserta didik. Metode pembelajaran Problem Based Learning adalah salah satu metode pembelajaran yang berfokus kepada peserta didik dan mempunyai tipe pembelajaran yang khas dengan mempelajari masalah berdasarkan lingkungan di sekitar peserta didik serta proses pembelajaran yang mengajak kepada peserta didik untuk melakukan uji coba, praktek atau melakukan penelitian dalam mencari solusi dari masalah tersebut (Alfiah, 2017).

Pada riset Santosa \& Setyawan (2014) hasil penelitiannya menyatakan bahwa terdapat hubungan antara fleksibilitas kognitif dengan metode focused coping pada mahasiswa dengan hasil variabel ranah kognitif dengan focused coping sebesar $48,2 \%$. Dengan hasil riset tersebut mahasiswa fast-track menggunakan keterampilan kognitif dalam mengembangkan kompetensi diri yang mereka miliki. Hasil penguatan keterampilan fleksibilitas menunjukkan bahwa kemampuan pemecahan masalah menjadi lebih baik

Problem Based Learning (PBL) sesuai dengan pembelajaran dengan konten IImu Pengetahuan Alam (IPA). Fauziah et al. (2013) memaparkan bahwa implementasi standar pendidikan yang baru sangat menekankan untuk belajar dengan cara saintifik yang bermaksud belajar dengan cara fokus kepada peserta didik dengan model Problem Based Learning (PBL) mampu meningkatkan hasil akhir belajar. Perancangan skenario model belajar dengan cara pendekatan saintifik berdasarkan riset mampu diimplementasi di kelas dengan model pembelajaran Problem Based Learning $(P B L)$ dengan baik. Pada riset Fauziah et al. (2013) memodifikasi rencana pelaksanaan pembelajaran elektronika dasar di Sekolah Menengah Kejuruan yang bercirikan model belajar dengan cara saintifik dengan model pembelajaran Problem Based Learning. PBL dengan ciri pengungkapan pendapat dan kemampuan untuk melakukan observasi merupakan upaya dalam meningkatkan keterampilan fleksibilitas. Rancangan pembelajaran dengan model saintifik dengan model Problem Based Learning (PBL), dan memperoleh respon yang baik dari guru dan peserta didik, sehingga mendapatkan hasil yang baik untuk peningkatan hard dan soft skill peserta didik dalam upaya pemecahan masalah.

Pada riset wijayanti (2020) mendapat hasil pretest kelas kontrol 50,44 dan kelas eksperimen 53,33 setelah dilakukan perlakuan pada kelas eksperimen dan dilakukan posttest kelas kontrol mendapat nilai 72,67 dan kelas kontrol sebesar 65,11 dan terdapat hasil yang berbeda dari hasil uji $t$ model Problem Based Learning (PBL) mampu merubah hasil belajar peserta didik. Sedangkan pada riset Zakiyah, H., \& Ulfa, N. (2018) membuktikan bahwa terjadi perubahan hasil belajar peserta didik dengan menerapkan model Problem Based Learning ( $P B L)$ dalam materi bahan kimia dalam kehidupan sehari-hari. Hasil penilaian rata-rata pada tes awal yaitu 56,72 , dan saat pengambilan nilai rata-rata peserta didik pada tes akhir yaitu 86,36 . Hasil uji-t pada taraf signifikan 0,05 bahwa t-tabel $=2,08$ dan t-hitung $=20,42$ sehingga terbukti t- hitung > t-tabel. Pada riset Sibarani (2016) dengan riset Pengaruh penerapan model pembelajaran Problem Based Learning (PBL) terhadap peningkatan hasil belajar dan aktivitas belajar kimia peserta didik SMA kelas XI IPA pada pokok bahasan hidrolisis garam, terjadi pengaruh hasil yang lebih baik yang diperoleh peserta didik. Dengan nilai peningkatan hasil belajar kelas eksperimen $83,75 \% \pm 0,089$ dan kelas kontrol 74,25\% \pm 0,106 . Dari nilai tersebut lalu dibandingkan dengan kelas yang menggunakan metode 
CTL dan model Problem Based Learning $(P B L)$ pada tahap awal setiap kelas dicari nilai awal sebelum menggunakan metode terkait dan setelah menggunakan metode yang ditentukan. Dalam perhitungan yang sudah di dapat dari masing-masing kelas bahwa hasil belajar IPS menunjukan kelas yang menerapkan model belajar CTL memperoleh nilai awal 60,67 dan nilai sesudah menggunakan metode CTL sebesar 80,33 dengan memiliki peningkatan nilai peserta didik mencapai 19,66. Dan kelas yang menggunakan model pembelajaran PBL memperoleh rata-rata awal sebesar 60,67 dan nilai akhir setelah menggunakan model PBL memperoleh nilai sebesar 84,50 dengan memperoleh peningkatan rata-rata peserta didik mencapai 23,33.

Riset yang berkaitan dengan model Problem Based Learning (PBL) dalam kemahiran berpikir (habits of mind) yaitu keterampilan berpikir fleksibel dengan titik fokus pada hasil belajar ranah kognitif yaitu : (1) Isro'atun, Abdurrozak dan Jayadinata, (2016), dengan penelitian "Pengaruh Model Problem Problem Based Learning (PBL) dengan Penilaian Berpikir Tingkat Tinggi Peserta didik dalam riset tersebut merupakan suatu penelitian yang tidak sama dengan yang akan dilaksanakan, pada riset ini hanya fokus untuk mencari hasil dari kemampuan berpikir tingkat tinggi. Sedangkan yang akan peneliti lakukan mencoba untuk menggunakan keterampilan fleksibilitas untuk hasil belajar peserta didik, (2) Sudarmin, Haryani, dan Lestari (2015), dengan judul "Pengembangan Instrumen Penilaian Habits Of Mind pada Pembelajaran IPA berbasis Proyek Tema Pencemaran Lingkungan untuk peserta didik SMP" riset tersebut merupakan suatu penelitian yang tidak sama dengan yang akan dilaksanakan, dalam riset itu instrumen fokus untuk mengambil penilaian tentang habits of mind berbasis proyek. Hal tersebut berbeda dengan yang akan dilakukan yaitu mencoba untuk menggunakan keterampilan fleksibilitas untuk hasil belajar peserta didik dengan model Problem Based Learning (PBL) (3), Tania, Sari, dan Fadiawati (2015), dengan penelitian "Model Discovery Learning dalam Meningkatkan Keterampilan Berpikir Luwes pada Materi Laju Reaksi" riset tersebut merupakan jenis yang tidak sama dengan yang akan dilaksanakan. Dikarenakan pada riset yang akan dilakukan dengan menerapkan model Problem Based Learning $(P B L)$ dengan keterampilan fleksibilitas untuk meningkatkan berpikir dengan fleksibilitas, dari hal tersebut peneliti tertarik untuk melakukan riset tersebut dengan tujuan apakah mampu untuk mengubah hasil belajar lebih baik dengan kemampuan berpikir fleksibilitas peserta didik dengan metode Problem Based Learning (PBL) (4) Rerung (2016) dengan judul "Pengaruh Model Pembelajaran Problem Based Learning (PBL) terhadap Hasil Belajar Kognitif Peserta didik pada Materi Usaha dan Energi di Kelas X Semester II SMA Negeri 14 Medan T.P 2016/2017" ) pada riset ini tidak sama dengan riset yang akan dilaksanakan. Dalam riset tersebut model pembelajaran Problem Based Learning (PBL) dibandingkan dengan model konvensional yang menggunakan metode ceramah, latihan dan penugasan. Sedangkan riset ini menerapkan model Problem Based Learning $(P B L)$ dengan penguatan keterampilan fleksibilitas akan dibandingkan dengan model pembelajaran konvensional berbasis STEM. Pembelajaran yang menerapkan metode STEM merupakan belajar dan pembelajaran dalam bidang science, technology, engineering, and mathematics. Model Problem Based Learning (PBL) dengan penguatan keterampilan fleksibilitas merupakan upaya dalam melibatkan peserta didik dalam proses pembelajaran, menjelaskan fenomena, meningkatkan minat diskusi antar peserta didik serta memecahkan masalah. Model Problem Based Learning ( $P B L$ ) dengan penguatan keterampilan fleksibilitas diharapkan mampu mem-berikan perubahan yang baik terhadap hasil belajar peserta didik kelas VII 
dengan konten IPA yaitu materi energi dalam kehidupan, sehingga peserta didik mampu untuk menyelesaikan masalah dengan baik.

\section{METODE}

Riset ini menerapkan penelitian kuantitatif dengan metode pendekatan eksperimen semu. Adapun desain riset yang digunakan adalah Nonequivalent Control Group Design (tabel 1). Riset dilakukan di SMP Tahfidz Al-Manshurin Malang pada tahun ajaran 2020/2021 dari bulan Maret sampai April 2020. Populasi riset ini adalah kelas VII A dan VII B dengan total keseluruhan 50 peserta didik. Pengambilan sampel dilakukan dengan teknik purposive sampling. Adapun sampel riset adalah kelas VII A sebagai kelompok kelas yang mendapat perlakuan (eksperimen) dengan 25 peserta didik dan kelas VII B sebagai kelas kontrol dengan 25 peserta didik. Teknik yang diterapkan saat pengambilan data yaitu dengan cara tes. Adapun pelaksanaan tes dilaksanakan pada saat peserta didik belum diberikan perlakuan (pretest) untuk mendapatkan data dari kemampuan peserta didik sebelum diberikan perlakuan dan pada saat setelah peserta didik telah diberikan perlakuan atau disebut (posttest) sehingga bisa mendapatkan data perolehan nilai peserta didik setelah mendapat perlakuan. Adapun beberapa pihak terkait dalam riset ini yaitu peneliti sendiri sebagai perancang dalam riset serta guru mata pelajaran IPA sebagai observer dalam riset ini dan sebagai pendamping di sekolah dan peserta didik kelas VII sebagai subyek dalam riset ini.

Tabel 1. Desain Riset

\begin{tabular}{cccc}
\hline Kelompok & $\begin{array}{c}\text { Pre } \\
\text { Test }\end{array}$ & Treatment & $\begin{array}{c}\text { Post } \\
\text { Test }\end{array}$ \\
\hline Eksperimen & $\mathrm{O}_{1}$ & $\mathrm{X}_{1}$ & $\mathrm{O}_{3}$ \\
Kontrol & $\mathrm{O}_{2}$ & $\mathrm{X}_{2}$ & $\mathrm{O}_{4}$ \\
\hline
\end{tabular}

HASIL

Uji normalitas diterapkan untuk mendapatkan data yang di dapat mengetahui berdistribusi normal atau tidak (Priyatno, 2009:28). Hal ini dilakukan untuk memudahkan perhitungan dan analisis data yang diperoleh di lapangan. Perhitungan untuk uji normalitas pada riset ini yaitu dengan uji Kolmogorov- Smirnov (Uji K-S) dengan nilai signifikansi $\alpha=0,05$. Uji normalitas data dilakukan dengan ketentuan sebagai berikut.

- Jika nilai sig. (2-tailed) $\geq 0,05$ maka data berdistribusi normal.

- Jika nilai sig. (2-tailed) $\leq 0,05$ maka data berdistribusi tidak normal.

Berdasarkan hasil pengolahan data (Tabel 2) diperoleh nilai signifikan pola belajar individu sebesar $0.829>0.05$ dengan demikian dapat disimpulkan bahwa data hasil belajar dari kelompok kontrol dan eksperimen berdistribusi normal atau memenuhi persyaratan uji normalitas.

Berdasarkan tabel diatas menunjukkan hasil perhitungan data analisis uji homogenitas nilai pretest diperoleh hasil uji levene sebesar 0.006 dengan nilai Sig. 0,005 adalah 0.939. Maka sesuai dengan ketentuan di atas bahwa jika nilai signifikansi atau nilai probabilitas lebih dari 0,05 maka $H_{0}$ diterima, yaitu data berasal dari populasi yang mempunyai varians sama atau homogen.

Tabel 2. Uji Normalitas

\begin{tabular}{ccc}
\hline $\begin{array}{c}\text { Asymp. Sig } \\
\text { (2 tailed) }\end{array}$ & Keterangan & Kesimpulan \\
\hline 0,829 & sig $>0,05$ & Normal \\
\hline
\end{tabular}

Tabel 3 Uji Homogenitas Ragam Data Hasil Belajar

\begin{tabular}{cccc}
\hline $\begin{array}{c}\text { Levene } \\
\text { Statistic }\end{array}$ & df1 & df2 & Sig. \\
\hline 0,006 & 1 & 48 & 0,939 \\
\hline
\end{tabular}


Tabel 4. Uji T Hasil Belajar Kognitif

\begin{tabular}{cccccccc}
\hline & \multicolumn{3}{c}{ Levene's Test for Equality of } & \multicolumn{3}{c}{ t-test for Equality of Means } \\
\cline { 2 - 8 } & $\mathrm{F}$ & Sig. & $\mathrm{t}$ & $\mathrm{df}$ & $\begin{array}{c}\text { Sig. (2- } \\
\text { tailed) }\end{array}$ & $\begin{array}{c}\text { Mean } \\
\text { Disfference }\end{array}$ & $\begin{array}{c}\text { Std. Error } \\
\text { Difference }\end{array}$ \\
\hline $\begin{array}{c}\text { Equal } \\
\text { variances } \\
\text { assumed } \\
\text { Equal } \\
\text { variances } \\
\text { not } \\
\text { assumed }\end{array}$ & 0,183 & 0,671 & 3,443 & 48 & 0,001 & 7,240 & 2,103 \\
\hline
\end{tabular}

Tabel 5. Perbandingan Hasil

\begin{tabular}{lcccc}
\hline \multicolumn{1}{c}{ Kelompok } & Skor & Pretest & Postest & Gain/Selisih \\
\hline Kontrol & Rata-rata & 60,68 & 74,52 & 13,86 \\
& STDEV & 8,78 & 7,15 & $-1,63$ \\
& MIN & 48,00 & 60,00 & 12 \\
& MAX & 75,00 & 90,00 & 15 \\
Eksperimen & Rata-rata & 56,44 & 81,76 & 25,32 \\
& STDEV & 9,99 & 7,70 & $-2,29$ \\
& MIN & 36,00 & 64,00 & 28 \\
& MAX & 84,00 & 96,00 & 12 \\
\hline
\end{tabular}

Rumusan pengujian hipotesis adalah sebagai berikut :

$H_{0}$ : Tidak terdapat pengaruh model Problem Based Learning (PBL) dengan penguatan keterampilan fleksibilitas terhadap hasil belajar kognitif peserta didik kelas VII SMP Tahfidz Al-Muflihun Malang.

$H_{1}$ : Terdapat pengaruh model Problem Based Learning (PBL) dengan penguatan keterampilan fleksibilitas terhadap hasil belajar kognitif peserta didik kelas VII SMP Tahfidz Al-Muflihun Malang.

Dari Tabel analisis uji-t sampel independent 2 tailed (Tabel 3) diketahui nilai $\mathrm{t}$ tabel dengan $\mathrm{df}=48$ dan taraf signifikansi $=$ 0,05 . Berdasarkan tabel 3 menunjukkan bahwa nilai t hitung 3.443 dan signifikansi 0.001 . Dari hasil tersebut dapat diketahui bahwa nilai signifikansi adalah $0.001<0.05$, sehingga bisa disimpulkan bahwa $\mathrm{HO}$ ditolak dan $\mathrm{H} 1$ diterima. jadi terdapat perbandingan nilai antara kelas eksperimen dengan menggunakan metode Problem Based Learning (PBL) dengan penguatan keterampilan fleksibilitas dengan kelas kontrol menggunakan metode metode konvensional.

Berdasarkan perbandingan hasil yang telah dipaparkan, menunjukkan skor rata-rata pada kelompok kontrol untuk pretest sebesar 60,68 sedangkan posttest sebesar 74,52. Nilai gain atau selisih dari pretest dan posttest sebesar 13,86. Pada skor minimal untuk pretest pada kelas kontrol adalah sebesar 48,00 sedangkan untuk posttest adalah sebesar 60,00 . Nilai gain atau selisih dari pretest dan posttest sebesar 12. Pada kelompok eksperimen, skor rata-rata untuk pretest sebesar 56,44 sedangkan posttest sebesar 81,76 . Nilai gain atau selisih dari pretest dan posttest sebesar 25,32 . Pada skor minimal untuk pretest pada kelas kontrol adalah sebesar 36,00 sedangkan untuk posttest adalah sebesar 64,00 . Nilai gain atau selisih dari pretest dan posttest sebesar 28 . Secara keseluruhan nilai gain untuk t hitung adalah sebesar 3.443. dari penjabaran data yang sudah dipaparkan 
bahwa kelas eksperimen memiliki perubahan nilai yang lebih besar dilihat dari gain antara skor pretest dan posttest yang diperoleh, dibandingkan skor peningkatan pada kelas kontrol.

Dari data hasil penilaian pretest dengan rata-rata nilai 60,68 untuk kelompok kontrol secara keseluruhan dan 56,44 untuk kelompok eksperimen secara keseluruhan berdasarkan uji homogenitas dengan nilai Sig 0,005 adalah 0,939. Maka sesuai dengan ketentuan di atas bahwa jika nilai probabilitas lebih dari 0,005 maka $\mathrm{H} 1$ diterima, yaitu perolehan data yang di dapat memiliki variansi yang sama atau homogen. Dari hasil nilai posttest yang dilakukan terhadap peserta didik kelompok kontrol dan kelompok eksperimen menunjukkan bahwa kelompok eksperimen yang menggunakan metode Pembelajaran Problem Based Learning (PBL) keterampilan fleksibilitas terhadap hasil belajar kognitif peserta didik smp kelas VII pada materi energi dalam sistem kehidupan mempunyai nilai dengan rata-rata lebih tinggi 81,76 jika dibandingkan dengan rata-rata nilai posttest kelompok kontrol dengan nilai rata-rata 74,52 untuk kelompok kontrol.

\section{PEMBAHASAN}

Riset ini merupakan penelitian eksperimen yang memiliki tujuan untuk mengetahui pengaruh Problem Based Learning (PBL) dengan keterampilan fleksibilitas pada mata pelajaran IPA terhadap hasil belajar kognitif peserta didik dengan subjek riset peserta didik kelas VII A dan kelas VII B SMP Tahfidz Al-Manshurin. Cakupan problem dalam riset ini terbatas pada pembelajaran menggunakan Problem Based Learning dengan fleksibilitas sebagai metode pembelajaran pada mata pelajaran IPA tentang energi dalam sistem kehidupan. Pengukuran hasil belajarnya juga terbatas hanya sebatas mengambil pengukuran dari hasil belajar ranah kognitif dengan menggunakan soal tes dan hasil unjuk kerja,portofolio dan proyek Hipotesis yang diajukan adalah "ada pengaruh Problem Based Learning (PBL) dengan fleksibilitas terhadap hasil belajar kognitif peserta didik pada mata pelajaran IPA peserta didik SMP Tahfidz Al-Manshurin".

Setelah melalui beberapa prosedur riset, hasil riset membuktikan bahwa hipotesis yang diajukan dapat diterima. Berdasarkan uji normalitas terhadap hasil belajar kedua kelompok sebelum mendapatkan perlakuan diperoleh nilai signifikansi $0,829>0,05$ dimana nilai tersebut menunjukkan bahwa sampel berdistribusi normal atau memiliki kemampuan yang sama rata. Penerimaan terhadap hipotesis dapat dibuktikan dengan adanya perbedaan dari semua nilai rata-rata pada kedua kelompok.

Pada saat pretest perolehan nilai rata-rata nilai kelompok eksperimen 56,44 sedangkan kelompok kontrol 60,68, dimana selisih nilai rata-rata kedua kelompok tidak terlalu jauh. Melainkan terdapat perbandingan yang signifikan setelah dilakukannya perlakuan terhadap kelas eksperimen menjadi 81,76 dan rata-rata nilai kelompok kontrol adalah 74.52 dari hasil tersebut maka dapat diketahui bahwa nilai perbandingannya kelas kontrol untuk pretest sebesar 60,68 sedangkan posttest sebesar 74,52. Nilai gain atau selisih dari pretest dan posttest sebesar 13,86. Pada kelompok eksperimen, skor rata-rata untuk pretest sebesar 56,44 sedangkan posttest sebesar 81,76 . Nilai gain atau selisih dari pretest dan posttest sebesar 25,32

Berdasarkan pengamatan peneliti selama proses pembelajaran dengan menggunakan metode Problem Based Learning (PBL) dengan keterampilan fleksibilitas mempunyai beberapa kelebihan yaitu antusiasme peserta didik dalam merespons materi meningkat karena lebih menarik karena mereka mendapat pengalaman belajar baru untuk saling mementingkan tujuan bersama dan saling menghargai pendapat satu sama lain dengan anggota kelompok, keaktifan peserta didik 
juga bertambah, peserta didik lebih fokus terhadap pelajaran untuk memikirkan pemecahan masalah dengan cara berpikir fleksibilitas, waktu dan tempat belajar yang lebih fleksibel dan materi lebih mudah dimengerti. Terbukti dari sikap peserta didik kelompok eksperimen lebih tenang, berkonsentrasi, tetapi peserta didik yang telah diberi perlakuan lebih bisa aktif bertanya dalam proses belajar.

Penerapan metode Problem Based Learning dengan keterampilan fleksibilitas menunjukkan pengalaman yang positif bagi peserta didik dalam memecahkan masalah dengan berpikir luwes atau lentur untuk saling menghargai pendapat dari anggota kelompok. Dalam menemukan adanya pengaruh tersebut dengan cara perbandingan hasil belajar kedua kelompok dengan perlakuan yang berbeda. Mula-mula dilakukan pre-test kepada masing-masing kelompok untuk menguji kemampuan awal mereka. Selanjutnya diberikan perlakuan atau pembelajaran dengan metode model Problem Based Learning dengan keterampilan fleksibilitas kepada kelas eksperimen, sedangkan kelompok kontrol hanya diberikan pembelajaran dengan metode konvensional (STEM). Tahap terakhir yaitu membandingkan kemampuan kedua kelompok yang mendapat perlakuan dan kelompok yang tidak mendapat perlakuan setelah diberi perlakuan dan ditemukan hasil adanya model Problem Based Learning dengan keterampilan fleksibilitas terhadap hasil belajar kognitif pada mata pelajaran IPA SMP Tahfidz AlManshurin".

Hal itu sesuai berdasarkan hasil riset ini sejalan dengan teori Costa dan Kallick (2008) yang menjelaskan bahwa Peserta didik yang mampu mengubah sudut pandangnya dengan berpikir fleksibel maka dia mampu untuk berbuat bersama dengan timnya untuk mendapatkan hasil penelitian yang baik. Mempunyai suatu ide atau gagasan yang mampu mengubah pikiran mereka berdasarkan informasi yang baru mereka dapatkan dan cara berpikir untuk memecahkan masalah yang sama. Kemampuan keterampilan fleksibilitas dapat membantu peserta didik untuk meningkatkan hasil belajar dengan masalah yang dihadapinya saat belajar menyelesaikan masalah yang ada di lingkungan sekitar (Indrawati, F., 2020). Peserta didik yang memiliki kebiasaan untuk berpikir maka mereka akan menjadi seseorang dengan pemikiran bersistem. Dengan adanya mereka mampu mengidentifikasi bagian-bagian yang mereka pelajari dan mampu untuk mengambil gambaran dalam menyelesaikan masalah (Costa \& Kallick, 2008). Selanjutnya peserta didik yang memiliki cara berpikir fleksibel akan banyak memberikan suatu ide atau gagasan dan memiliki peran yang aktif selama proses belajar (Costa \& Kallick, 2012). Peningkatan nilai hasil belajar peserta didik kelas VII pada materi energi dalam kehidupan dengan menggunakan model Problem Based Learning (PBL) dengan keterampilan fleksibilitas menunjukkan bahwa peserta didik dapat lebih memahami materi mengenai energi dalam sistem kehidupan yang diajarkan, dan lebih bermakna hal tersebut sejalan dengan teori yang dinyatakan oleh Wulandari dan Surjono (2013), ketika proses kegiatan belajar mengajar berlangsung peserta didik diberi kesempatan untuk menyelesaikan suatu masalah yang diberikan, merumuskan masalah dan mendiskusikan hingga mendapat pemecahan masalah. Pada riset (Indriani, 2017) dengan menerapkan model Problem Based Learning (PBL) terhadap ketangkasan berpikir fleksibel peserta didik dengan materi pencemaran lingkungan, ditemukan bahwasanya pembelajaran dengan metode Problem Based Learning $(P B L)$ dapat memberi peningkatan dalam berpikir fleksibel peserta didik pada materi pencemaran lingkungan.

Dalam proses kegiatan belajar mengajar dengan model Problem Based Learning $(P B L)$ peserta didik memiliki sifat 
yang sangat antusias dalam menyelesaikan tugasnya dikarenakan mereka memiliki tanggung jawab yang kompleks dengan belajar cara mereka sendiri (Indrawati, F. A., \& Wardono, W., 2019)

Riset ini sesuai dengan riset yang telah dilakukan Ramlawati, R (2017) dalam implementasi model Problem Based Learning (PBL) terhadap hasil belajar IPA bahwasanya ada perbedaan antara hasil belajar peserta didik yang menggunakan proses belajar dengan model Problem Based Learning ( $P B L)$ dengan peserta didik yang menggunakan model pembelajaran konvensional. Riset lainnya mengungkapkan bahwasanya model Problem Based Learning $(P B L)$ dapat secara signifikan meningkatkan penguasaan konsep kalor dibandingkan dengan model pembelajaran konvensional. Hal ini berarti model Problem Based Learning $(P B L)$ sesuai dengan kebutuhan dalam belajar pada materi IPA. Peningkatan nilai rata-rata hasil belajar peserta didik kelas VII pada materi energi dalam sistem kehidupan menggunakan model Problem Based Learning (PBL) dengan keterampilan fleksibilitas menunjukkan bahwa peserta didik lebih mudah untuk memahami mengenai energi dalam sistem kehidupan yang diajarkan, dan lebih bermakna selaras dengan teori yang dinyatakan oleh Wulandari \& Surjono (2013: 180), ketika proses belajar mengajar berlangsung para peserta didik diberi peluang untuk mencoba untuk menyelesaikan suatu masalah, merumuskan masalah dan mendiskusikan hingga mendapat pemecahan masalah.

Berdasarkan hasil riset ini sejalan dengan teori Costa dan Kallick (Costa \& Kallick, 2012) yang menyatakan bahwa Peserta didik yang berpikir fleksibel mampu membuat arah sudut pandangnya menjadi orang yang memiliki sifat mengutamakan kebersamaan tujuan tim. Mempunyai kemampuan cara berpikir mereka dengan hasil pencarian yang didapatkan, serta mampu untuk mencari solusi dari masalah yang dihadapi (Costa \& Kallick, 2012, hlm.
22). Peserta didik yang telah memiliki kebiasaan untuk berpikir fleksibel maka mereka akan menjadi orang yang berpikir secara efektif. Mereka bisa memiliki sifat untuk mengidentifikasi, menganalisis masalah yang dihadapi dengan cara mampu menggambarkan suatu penyelesaian dari gambaran tersebut. Selanjutnya peserta didik yang berpikir fleksibel akan memiliki ide atau pendapat serta mereka berperan secara aktif dalam belajar (Costa \& Kallick, 2012, hlm. 197).

Bagi peserta didik yang memiliki sifat berpikir fleksibel mengetahui mereka memiliki sesuatu yang dapat mereka kembangkan, memahami hubungan antara tujuan dan cara menyelesaikan suatu masalah, mereka mampu untuk bekerja sesuai dengan perintah dan aturan. Dan mereka mengetahui apabila mereka melakukan suatu kesalahan jika mereka melanggarnya. Dengan adanya hal tersebut, keluwesan dalam berpikir sangat penting dalam yang akan mereka pecahkan, dan bisa membuat seseorang menyadari perbedaan pendapat dalam memaknai sesuatu. Peserta didik yang telah memiliki kebiasaan berpikir untuk menyelesaikan masalah mereka akan menjadi seorang yang berpikir secara efektif. Mereka mampu untuk menganalisis dan mengidentifikasi sebuah masalah dengan cara menggambarkan suatu masalah tersebut dan mengambil langkah penyelesaian yang efektif. Selanjutnya peserta didik yang memiliki konsep untuk berpikir secara fleksibel mereka mampu memberikan ide atau gagasan yang baik dalam proses menyelesaikan masalah tersebut (Costa \& Kallick, 2012).

\section{SIMPULAN}

Dari hasil riset maka dapat diambil kesimpulan adanya pengaruh Problem Based Learning ( $P B L$ ) dengan penguatan keterampilan fleksibilitas terhadap hasil belajar peserta didik, dengan mendapatkan nilai rata-rata 81.76 untuk kelas yang diberikan perlakuan dan sebelum perlakuan 
mendapat nilai rata-rata 74.52, dan terdapat selisih sebesar 7,24. maka dapat disimpulkan adanya pengaruh Problem Based Learning $(P B L)$ dengan penguatan keterampilan fleksibilitas dengan perolehan nilai belajar kognitif peserta didik kelas VII SMP Tahfidz Al-Muflihun Malang. Hasil uji-t sampel independent 2 tailed yang dibawah dari 0,05 dengan 0,001 < 0,05, dan bisa diambil keputusan $\mathrm{H}_{1}$ diterima. Saran dalam riset ini bagi guru adalah Problem Based Learning (PBL) dengan penguatan keterampilan fleksibilitas bisa menjadi metode dalam pembelajaran IPA sehingga dapat meningkatkan hasil belajar. Dengan cara peserta didik mencari solusi pemecahan masalah melalui informasi yang didapat dan mampu untuk mempresentasikannya.

\section{REFERENSI}

Abdurrozak, R., \& Jayadinata, A. K. (2016). Pengaruh Model Problem Based Learning Terhadap Kemampuan Berpikir Kreatif Siswa. Jurnal Pena IImiah, 1(1), 871-880.

Alfiah, A. N. (2017). Penerapan Model Problem Based Learning Untuk Meningkatkan Keaktifan Dan Hasil Belajar Ipa Peserta didik Kelas V. Edcomtech Jurnal Kajian Teknologi Pendidikan, 2(1), 11-18.

Asdiansyah, A., Mustaji, M., \& Sitompul, N. C. (2020). Pengaruh Project Based Learning An Minat Belajar Terhadap Hasil Belajar Menggambar Bentuk (Still Life) dalam Pelajaran Visual Art. Edcomtech Jurnal Kajian Teknologi Pendidikan, 5(2), 119-128.

Astuti, Puji, Retno., Junaedi dan Iwan. (2012). Peningkatan Aktivitas dan Hasil Belajar Melalui PBL pada Peserta didik Kelas $X$ SMAN 4 Pekalongan. Jurnal unnes, Vol. 22, No. 22. Butler, L. P. (2020). The Empirical Child? A Framework for Investigating the Development of Scientific Habits of Mind. Child Development Perspectives, 14(1), 3440.

Chen, X., Wiesmeier, M., Sardans, J., Van Zwieten, L., Fang, Y., Gargallo-Garriga,
A., Chen, Y., Chen, S., Zeng, C., \& Peñuelas, J. (2020). Effects of crabs on greenhouse gas emissions, soil nutrients, and stoichiometry in a subtropical estuarine wetland. Biology and Fertility of Soils, 1-14.

Costa, A. L., \& Kallick, B. (2008). Learning and leading with habits of mind: 16 essential characteristics for success. ASCD.

Costa, A. L., \& Kallick, B. (2012). Belajar dan Memimpin dengan "Kebiasaan Pikiran 16" Karakteristik Penting untuk Sukses. Jakarta: PT. Indeks.

Darmawan, W., Kuswandi, D., \& Praherdhiono, H. (2020). Pengaruh Blended Learning Berbasis Flipped Classroom Pada Mata Pelajaran Prakarya Terhadap Hasil Belajar Peserta didik Kelas X SMK. Edcomtech Jurnal Kajian Teknologi Pendidikan, 5(2), 170-179.

Fadly, Aditiya. (2012). Peningkatan Aktivitas dan Hasil Belajar Peserta didik Melalui Model Pembelajaran (PBL) Studi Pada Kelas X Bisnis dan Manajemen Mata pelajaran Kewirausahaan di SMK Ardjuna 1 Malang. Jurnal Fisika Indonesia, Vol. XVII, No. 49 ISSN: 14102994

Fauziah, R., Abdullah, A. G., \& Hakim, D. L. (2013). Pembelajaran saintifik elektronika dasar berorientasi pembelajaran berbasis masalah. Innovation of Vocational Technology Education, 9(2), 165-178.

Gloria, R. Y., Sudarmin, W., \& Indriyanti, D. R. (2020). Formative assessment with understanding by design to improve students' habits of mind. Journal of Physics: Conference Series, 1521, 042094.

Indriani, U. (2017). Penerapan Model Problem Based Learning Untuk Meningkatkan Kemampuan Berpikir Fleksibel Peserta didik Pada Konsep Pencemaran Lingkungan. FKIP UNPAS.

Kusumo, G. T. (2020). Pengaruh pengungkapan emisi gas rumah kaca terhadap nilai perusahaan: Tipe 
industri sebagai pemoderasi. Widya Mandala Catholic University Surabaya.

Lestari, D., Sudarmin, S., \& Haryani, S. (2015). Pengembangan Instrumen Penilaian Habits Of Mind Pada Pembelajaran IPA Berbasis Proyek Tema Pencemaran Lingkungan Untuk Siswa SMP. Unnes Science Education Journal, 4(1), 796806

Praherdhiono, H., Adi, E. P., \& Prihatmoko, Y. (2018). Konstruksi demokrasi belajar berbasis kehidupan pada implementasi LMS dan MOOC. Edcomtech Jurnal Kajian Teknologi Pendidikan, 3(1), 21-28.

Praherdhiono, H., Setyosari, P., Degeng, I. N. S., Slamet, T. I., Surahman, E., Adi, E. P., Degeng, M. D. K., \& Abidin, Z. (2019). Teori dan Implementasi Teknologi Pendidikan: Era Belajar Abad 21 dan Revolusi Industri 4.0. Seribu Bintang.

Ramlawati, R., \& Yunus, S. R. (2017). Pengaruh model PBL (Problem Based Learning) terhadap motivasi dan hasil belajar IPA peserta didik. Sainsmat. Jurnal IImiah IImu Pengetahuan Alam, 6(1), 1-14

Rerung, N., Sinon, I. L., \& Widyaningsih, S. W. (2017). Penerapan model pembelajaran problem based learning (PBL) untuk meningkatkan hasil belajar peserta didik SMA pada materi usaha dan energi. Jurnal Ilmiah Pendidikan Fisika Al-Biruni, 6(1), 47-55.

Santosa, E. O., \& Setyawan, I. (2014). Hubungan antara Fleksibilitas Kognitif dengan Problem Focused Coping Pada Mahapeserta didik Fast-Track Universitas Diponegoro. Empati, 3(2), 139-146.

Sari, Fadiawati, dan Tania. (2015). Model Discovery Learning Dalam Meningkatkan Keterampilan Berpikir Luwes Pada Materi Laju Reaksi Jurnal Pendidikan dan Pembelajaran Kimia.
Jurnal Vol. 4, No.2 Edisi Agustus 2015, 556-567

Sibarani, Hotmian . (2016). Pengaruh Penerapan Model Pembelajaran Problem Based Learning (Pbl) Terhadap Peningkatan Hasil Belajar Dan Aktivitas Belajar Kimia Peserta didik Sma Kelas Xi Ipa Pada Pokok Bahasan Hidrolisis Garam. online http://digilib.unimed.ac.id/id/eprint/2 0797

Toraman, Ç., Özdemir, H. F., Kosan, A. M. A., \& Orakci, S. (2020). Relationships between Cognitive Flexibility, Perceived Quality of Faculty Life, Learning Approaches, and Academic Achievement. International Journal of Instruction, 13(1), 85-100.

Wijayanti .(2020). Pengaruh Model Model Problem Based Learning (PBL) Terhadap Hasil Belajar Peserta didik Pada Pembelajaran Ipa Kelas VII Semester II Smp Negeri 35 Medan T.P. 2019/2020 Available online http://jurnal.unimed.ac.id/2012/index .php/inpafi e-issn 2549-8258, p-issn 2337-4624

Wijayanti, A., \& Wulandari, T. (2016). Efektivitas model CTL dan model PBL terhadap hasil belajar IPS. Harmoni Sosial: Jurnal Pendidikan IPS, 3(2), 112124.

Wulandari, B., \& Surjono, H. D. (2013). Pengaruh problem-based learning terhadap hasil belajar ditinjau dari motivasi belajar PLC di SMK. Jurnal Pendidikan Vokasi, 3(2), 178-191.

Zakiyah, H., \& Ulfa, N. (2018). Pengaruh Model Pembelajaran PBL (Problem Based Learning) Terhadap Hasil Belajar Peserta didik Pada Materi Bahan Kimia Dalam Kehidupan Sehari-Hari. Lantanida Journal, 5(2), 106-118. 